\title{
Effects of Surface-Water Use on Domestic Groundwater Availability and Quality During Drought in the Sierra Nevada Foothills, California
}

\section{Background}

Approximately 2 million California residents rely on privately owned domestic wells for drinking water. During the California drought of 2012-16 groundwater levels declined in many parts of the state and wells were deepened in response. Most of the wells deepened during this time were domestic wells that were drilled into fractured bedrock throughout the Sierra Nevada foothills region of northern California (California Department of Water Resources, 2014). To understand the impacts of extreme drought on groundwater supply availability and quality in this setting, the United States Geological Survey (USGS) completed a geochemical survey of domestic wells throughout the Yuba and Bear River watersheds during 2015-16 (fig. 1) as part of the State Water Board's Groundwater Ambient Monitoring and Assessment Program Priority Basin Project (GAMA-PBP). This fact sheet highlights key findings from the GAMA-PBP assessment (Levy and others, 2020).

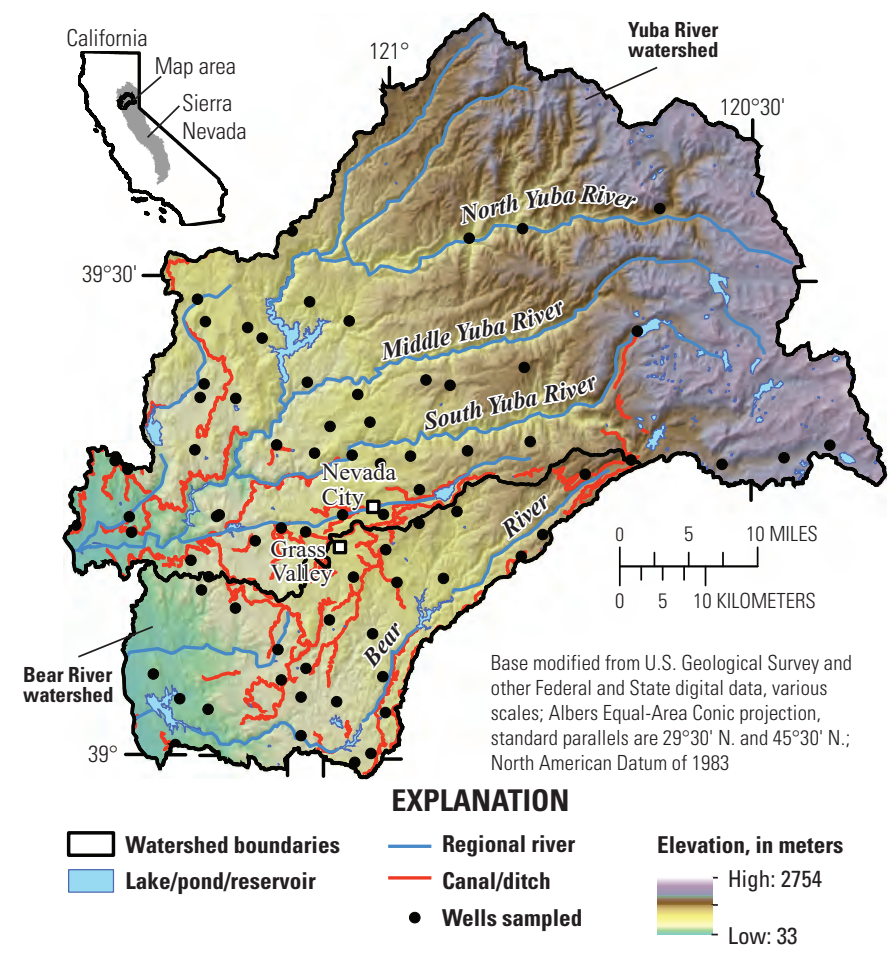

Figure 1. Yuba and Bear River watersheds study area with locations of sampled domestic groundwater wells, major surface water bodies, and water distribution infrastructure.

\section{A Vulnerable Population}

The Sierra Nevada foothills of northern California drain to intensively managed tributaries of the Sacramento River. Regional river water typically is channeled through extensive water-distribution infrastructure and hydroelectric systems and routed to downstream users or diverted for local use. Diverted surface waters are either treated and delivered to population centers for public drinking water or conveyed through extensive canal and ditch networks for irrigation (fig. 1). In the Yuba and Bear River watersheds, rapid growth and expansion of the rural population outside of the areas connected to public water systems has resulted in a high density of households that are reliant on domestic wells for their drinking-water supply (Johnson and Belitz, 2015).

\section{Key Points}

- Many residents in the northern Sierra Nevada foothills rely on domestic groundwater supply from fractured rock aquifers, where groundwater levels have declined during the past 50 years due to rapid growth of the rural population.

- Geochemical fingerprinting identified two primary sources of recharge to domestic wells: local precipitation and surface water diverted for human-use.

- Diverted surface water can be an important component of groundwater recharge during drought and can recharge aquifers either by irrigation return flows or seepage from distribution infrastructure.

- Wells that received recharge from diverted surface water had elevated levels of nitrate and coliform bacteria compared to those replenished exclusively by precipitation.

- It is important to consider the impacts of surface-water development on the quantity and quality of groundwater recharge in rapidly developing montane watersheds. 
Domestic wells in the Yuba and Bear River watersheds typically draw water from what are called "fractured rock aquifers." The water-bearing bedrock fractures that supply these wells are much more difficult to map and characterize than valley-floor groundwater basins and comparatively little is known about supply vulnerability in the highlands. Wellcompletion reports that were submitted to the California Department of Water Resources between 1965 and 2014 can be used to shed light on groundwater trends in the Sierra Nevada foothills. Over 20,000 well-completion reports available in the study area, along with census data, show that both rural population and median well depth nearly quadrupled from 1965 to 2014 , indicating (1) an increased demand on bedrock aquifers for domestic drinking-water supply, and (2) a resulting gradual decline of regional groundwater levels during the past 50 years (fig. 2).

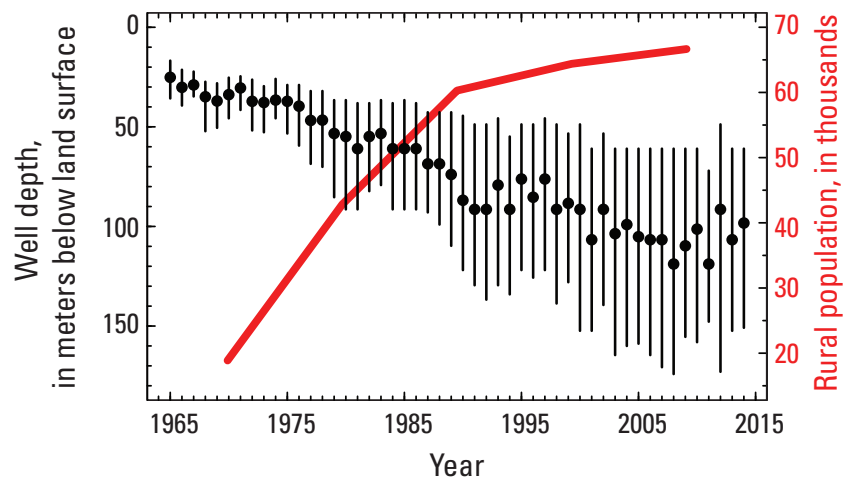

Figure 2. Well-completion depths in the study area binned by year: points represent the median of annual data and whiskers span the interquartile range. Rural population (red line) represents census population data for the unincorporated area of Nevada County from 1970 to 2010.

\section{Fingerprinting Sources and Seasonality of Recharge}

Geochemical "fingerprinting" tools help scientists to understand the sources of water that replenish or "recharge" fractured rock aquifers and at what time of year the recharge occurs. This information can be used to identify how groundwater resources in the foothills could be vulnerable to climate change. To understand regional vulnerabilities of domestic groundwater supplies to extreme drought, the USGS obtained geochemical fingerprint information from water samples collected from 75 domestic wells or springs in the Yuba and Bear River watersheds during 2015-16 (Jasper and others, 2017; Levy and Faulkner, 2019).

One geochemical fingerprint used in this study was the isotopic composition of oxygen and hydrogen in the water molecules constituting the groundwater itself. Stable isotopes of water have natural variations in mass and are expressed in "delta" notation, which is a measure of the proportion of heavier to lighter isotopes compared to that of a reference standard (U.S. Geological Survey, 2014). Water molecules with slightly different masses behave differently in environmental processes such as evaporation or precipitation and can indicate differing histories of groundwater recharge sources.

Because the isotopic composition of water precipitating from clouds as rain or snow becomes progressively lighter (more negative) at higher altitudes, isotopes of groundwater can be measured to determine the elevation at which precipitation recharged the aquifer. Groundwater oxygen isotopes (delta oxygen-18) at individual wellhead elevations closely tracked the expected trend for atmospheric precipitation, indicating that most of the recharge to the wells is from precipitation that falls at elevations that are close or "local" to the wellhead and does not originate from much higher in the watersheds (fig. $3 A$ ).

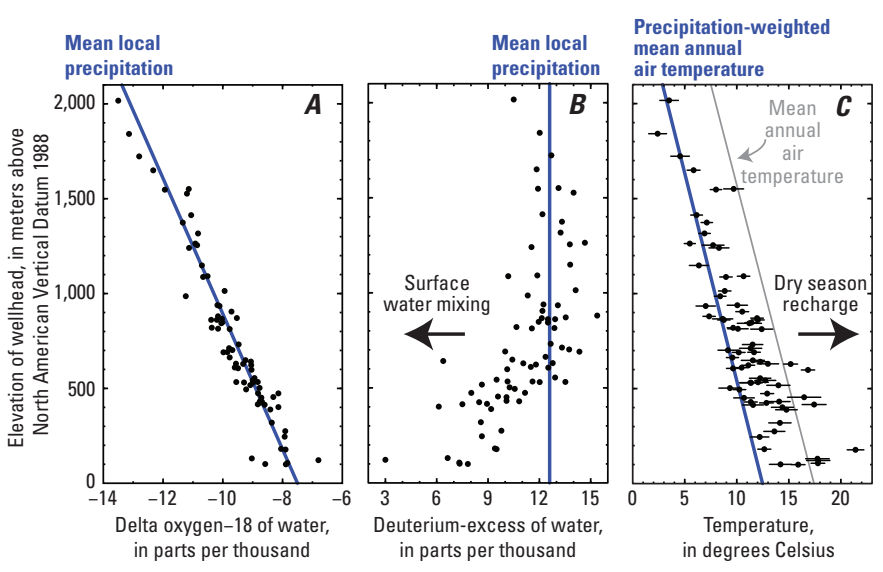

Figure 3. Variation of $A$, groundwater oxygen-18; $B$, deuteriumexcess; and $C$, noble-gas-derived recharge temperatures with wellhead elevation.

Another isotopic fingerprint called "deuterium-excess" ( $d$-excess) describes the difference between the values of oxygen and hydrogen isotope compositions and can be used to tell if groundwater has mixed with surface water (Levy and others, 2020). Unlike the individual water isotopes, the $d$-excess of precipitation does not change with elevation and is close to 12 parts per thousand throughout the study area. However, when water is exposed to the atmosphere at the land surface in open water bodies it partially evaporates, which causes its $d$-excess value to decrease. This process tags surface water with a unique geochemical fingerprint that contrasts with that of local precipitation.

Groundwater samples obtained from wells in the upper part of the study area had $d$-excess values close to 12 parts per thousand, which reflects the unique fingerprint of local precipitation. At lower elevations, however, nearly one-quarter of the sampled wells had waters with lower $d$-excess values, which is indicative of mixing with recharge derived in part from surface water (fig. 3B). Mixing calculations indicate that waters from these lower elevation wells were composed of an average of 30-percent surface water mixed with 70-percent water from local precipitation. Effects of surface-water mixing on groundwater $d$-excess are more pronounced at low-elevation sites that receive less annual rainfall than those located higher up in the watersheds. 
These sample results were compared with a completely different set of geochemical fingerprints from concentrations of dissolved noble gases. Noble gases (neon, argon, krypton, and xenon) are naturally present in the atmosphere, and their solubility in water depends on temperature. Thus, the concentrations of noble gases dissolved in groundwater can be used to calculate the temperature of water at the time it recharges the aquifer. Groundwater samples obtained from higher elevations had recharge temperatures closer to cool winter temperatures, which is when the bulk of annual precipitation falls in the study area (fig. $3 C$ ). Many of the samples obtained from lower elevations had groundwater recharge temperatures that were elevated from either winter wet-season temperatures or mean annual air temperatures, leading to the conclusion that some of the recharge occurred during the warm summer dryseason when there is virtually no rainfall.

Human "replumbing" of the Yuba and Bear River watersheds can explain the geochemical fingerprints of dryseason recharge by surface-water that were measured in groundwaters of the lower watersheds. Water-distribution infrastructure diverts river water originating at high elevations through extensive canal networks and reservoirs to lower elevations for human-use (fig. 1). The water acquires the evaporative fingerprint of lower $d$-excess values as it resides in canals, reservoirs, and other surface impoundments. The surface water can then enter the aquifer by seepage from waterdistribution infrastructure or by deep percolation of irrigation water applied to the land surface (fig. 4). During the summer or extended drought when little precipitation falls, diverted surface water becomes a greater proportion of the total annual recharge budget. Unlike local streams and rivers, flows through waterdistribution infrastructure increase during dry times to meet
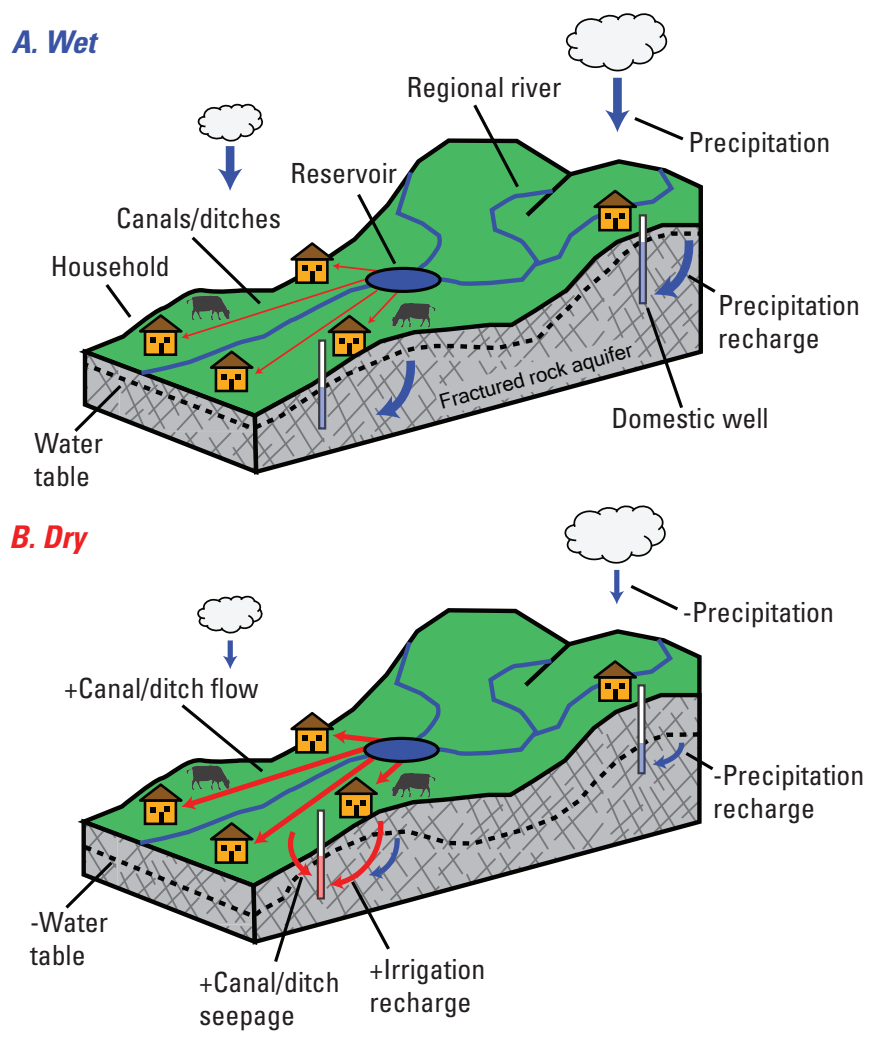

Figure 4. Conceptual models of the study-area hydrology under $A$, wet, and $B$, dry conditions. human demand, which explains the warm dry-season recharge temperatures at lower elevations. Without human replumbing of the watershed, there would be little recharge during dry times.

\section{Impacts of Surface-Water Recharge on Groundwater Quality}

Groundwater recharged from surface-water sources can be vulnerable to certain types of contamination. Two vulnerability indicators of contamination associated with surface-water recharge are nitrate and coliform bacteria. Nitrate is an essential nutrient for plant and animal life and is concentrated in fertilizers and wastewater. Concentrations of groundwater nitrate greater than 1 milligram per liter $(\mathrm{mg} / \mathrm{L})$ indicate contamination by human activities (Burow and others, 2010). Nitrate concentrations were greater than $1 \mathrm{mg} / \mathrm{L}$ in 20 percent of the wells sampled, and these wells were predominantly in areas with lower groundwater $d$-excess values, indicating the zones where diverted river water is a larger proportion of the annual recharge budget (fig. 5). No wells had nitrate levels above the state and federal regulatory threshold of $10 \mathrm{mg} / \mathrm{L}$. In the Yuba-Bear River watersheds, there is very little commercial agriculture and the most likely sources of nitrate contamination are drainage from forage pasture and family gardens/orchards, which are the top uses of irrigation water by acreage in the region, in addition to human-waste streams such as septic leachate and wastewater treatment-plant discharges.

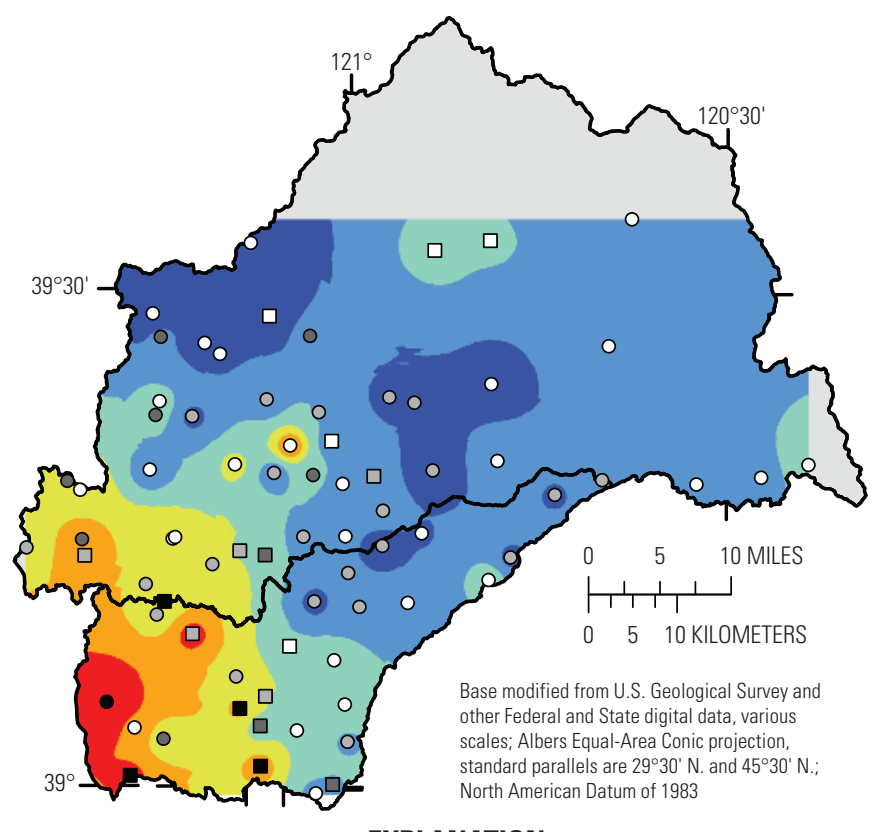

EXPLANATION

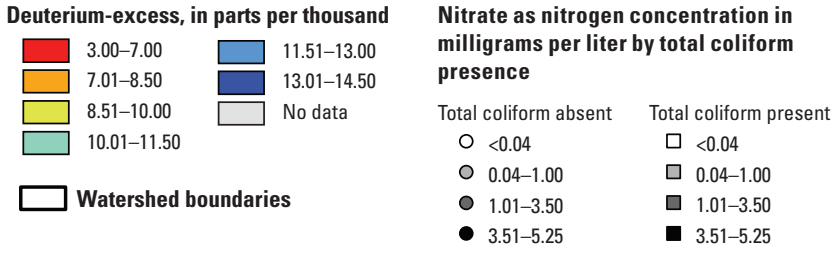

Figure 5. Map of study area shaded by interpolated values of groundwater deuterium-excess with point measurements of groundwater nitrate and presence or absence of total coliform bacteria. 
Coliform bacteria exist naturally in soils and surface waters and are present in the digestive tracts of warm-blooded animals, including humans (California State Water Resources Control Board, 2016). The presence of total coliform bacteria (TC) in a drinking-water supply is a general vulnerability indicator of microbiological contamination and does not necessarily indicate that pathogenic species are present. Total coliform bacteria were detected in 22 percent of the wells sampled (fig. 5).

Most of the 17 wells that tested positive for TC also were clustered in low-elevation areas that recieved recharge from diverted surface water (fig. 5). Total coliform was also present in three out of the four springs sampled at higher elevations, suggesting that it may occur naturally in surface water throughout the study area. However, TC was present in four out of the five wells with the highest nitrate concentrations, indicative of anthropogenic contamination sources at lower elevations (fig. 5). These data show important linkages between recharge from untreated surface water and water-quality degradation that could increase as precipitation inputs decline during prolonged droughts.

\section{Implications for Integrated Water Resources Management}

Understanding how climate change could affect groundwater recharge in intensively managed watersheds is essential to managing regional vulnerabilities of drinking-water resources. Groundwater supply from fractured bedrock aquifers of the Sierra Nevada foothills and other similar settings is highly dependent on inputs from local precipitation and, therefore, is vulnerable to hydrologic drought. However, homeowner wells located within surface-water irrigation districts also can derive some of their well water indirectly from surface waters diverted for human use that can recharge aquifers during dry times when demand peaks. Human replumbing of watersheds is a doubleedged sword with respect to groundwater resources; although it can increase recharge to domestic wells during drought, it also can introduce water-quality vulnerabilities associated with contaminants from untreated surface-water sources. The consideration of groundwater and surface-water interactions and associated water-quality impacts is vital for comprehensive sustainability planning in California and other rapidly developing waterscapes.

\title{
References Cited
}

\author{
By Zeno F. Levy, Miranda S. Fram, and Kim A. Taylor
}

Burow, K.R., Nolan, B.T., Rupert, M.G., and Dubrovsky, N.M., 2010, Nitrate in groundwater of the United States, 1991-2003: Environmental Science \& Technology, v. 44, no. 13, p. 4988-4997, https://doi.org/10.1021/es100546y.

California Department of Water Resources (DWR), 2014, Report to the Governor's drought task force-Groundwater basins with potential water shortages and gaps in groundwater monitoring: Sacramento, Calif., DWR, 51 p., https://water.ca.gov/LegacyFiles/ waterconditions/docs/Drought_Response-Groundwater_Basins_April30_Final_BC.pdf.

California State Water Resources Control Board, 2016, Groundwater information sheet, bacterial indicators: California State Water Resources Control Board, GAMA Program information, 7 p., https:/www.waterboards.ca.gov/gama/docs/coc_bacteria indicators.pdf.

Jasper, M., Bennett, G.L., and Fram, M.S., 2017, Groundwater-quality data in the Yuba and Bear Watersheds Shallow Aquifer Study Unit, 2015-2016 - Results from the California GAMA Priority Basin Project: U.S. Geological Survey data release, https://doi.org/10.5066/F73F4MS9.

Johnson, T.D., and Belitz, K., 2015, Identifying the location and population served by domestic wells in California: Journal of Hydrology—Regional Studies, v. 3, p. 31-86, https://doi.org/10.1016/j.ejrh.2014.09.002.

\section{For more information}

Technical reports and hydrologic data collected for the GAMA Program may be obtained from:

\section{GAMA Project Chief}

U.S. Geological Survey

California Water Science Center

6000 J Street, Placer Hall

Sacramento, CA 95819

Telephone number: (916) 278-3000

WEB: https://ca.water.usgs.gov/gama

GAMA Program Unit Chief

State Water Resources Control Board

Division of Water Quality

PO Box 2231, Sacramento, CA 95812

Telephone number: (916) 341-5855

https://www.waterboards.ca.gov/gama
Levy, Z.F., and Faulkner, K.E., 2019, Dissolved noble gas concentrations and modeled recharge temperatures for groundwater from northern Sierra Nevada Foothills Shallow Aquifer Assessment Study Units, 2015-2017-Results from the California GAMA Priority Basin Project: U.S. Geological Survey data release, https://doi.org/10.5066/P9YETK9P.

Levy, Z.F., Fram, M.S., Faulkner, K.E., Alpers, C.N., Soltero, E.M., and Taylor, K.A., 2020, Effects of montane watershed development on vulnerability of domestic groundwater supply during drought: Journal of Hydrology, [in press], https://doi.org/10.1016/j.jhydrol.2020.124567.

U.S. Geological Survey, 2014, Resources on isotopes-Fundamentals of stable isotope geochemistry: https://wwwrcamnl.wr.usgs.gov/isoig/res/funda.html. 